\title{
Teacher Practice and Integration of ICT: Why Are or Aren't South African Teachers Using ICTs in Their Classrooms
}

\author{
Marien Alet Graham \\ Department of Science, Mathematics and Technology Education, Faculty of Education, \\ University of Pretoria, Pretoria, South Africa, marien.graham@up.ac.za
}

\section{Gerrit Stols}

Department of Science, Mathematics and Technology Education, Faculty of Education, University of Pretoria, Pretoria, South Africa, gerrit.stols@up.ac.za

\section{Ruan Kapp}

Department of Science, Mathematics and Technology Education, Faculty of Education, University of Pretoria, Pretoria, South Africa, ruan@itdesign.co.za

The question, "how does the UTAUT variables (Performance Expectancy, Effort Expectancy, Social Influence and Facilitating Conditions) influence mathematics teachers' acceptance of ICT integration?" was investigated, using the four constructs of the UTAUT framework. The four constructs were hypothesised to influence teachers' use of ICTs within the educational domain. Results from structural equation modelling showed that three of the four constructs were statistically significant. This study showed why South African mathematics teachers integrate ICTs into their classrooms. Once the 'why' is understood, changes can be made to further, and more successfully, enhance ICT adoption in mathematics classrooms. Further, this paper also offers recommendations to maximise the use of ICTs in education.

Keywords: education, ICT integration, technology acceptance, UTAUT, mathematics education

\section{INTRODUCTION}

In South Africa, learners, especially from under-resourced schools, have consistently underachieved in subjects such as Mathematics and Science (Reddy et al., 2012, 2016). The South African government, by means of the Department of Basic Education (DBE), has turned to new technologies to help improve teaching and learning and to redress past inequalities in schools. However, Karsenti, Collin and Harper-Merrett (2011) point out that this intervention has made little progress. The latter is accentuated in the DBE's

Citation: Graham, M. A., Stols, G., \& Kapp, R. (2020). Teacher Practice and Integration of ICT: Why Are or Aren't South African Teachers Using ICTs in Their Classrooms. International Journal of Instruction, 13(2), 749-766. https://doi.org/10.29333/iji.2020.13251a 
Action Plan to 2019 report, where the department concedes that Information and Communication Technology (ICT) enhanced learning had not advanced in South Africa as predicted (DBE, 2015, p. 14). Thus, leaving researchers to question the integration of technology within the education sector.

According to Buabeng-Andoh (2012), technology adoption and integration, in teaching and learning have remained inadequate, in many countries, despite all the investments in infrastructure, equipment and professional development of teachers. Ertmer and Ottenbreit-Leftwich $(2012,2013)$, further concludes that access to ICT is no longer a notable barrier to its integration in the classroom. Mundy, Kupczynski and Kee (2012) state that teachers, even those that grew up using technology, are not utilising it in their practise. Recent literature suggests that South Africa is no different, as only a small number of South African teachers are effectively integrating technology in the classroom (Nkula \& Krauss, 2014; Padayachee, 2016).

The DBE estimates that a mere $26 \%$ of South African teachers are equipped with basic technology skills, with only $7 \%$ functioning at an intermediate level of competency (Alfreds, 2016). Mooketsi and Chigona (2014) in their study, found that there was a disparity between what government expected and the practices of teachers at classroom level. The 'Action plan to 2019' report echoes the latter stating that 'there is still a major weakness in the system when it comes to the implementation of ICT to improve the teaching and learning process" (Department of Basic Education [DBE], 2015, p. 14).

As this study aims to investigate factors affecting the integration of ICT by mathematics teachers in South African classrooms, previous appropriate findings on mathematics education in South Africa is discussed first followed by a discussion on the importance of ICT integration in the learning and teaching of mathematics.

The mathematics achievement of South African learners ranked among the lowest in several international comparative assessments, for example, in Trends in International Mathematics and Science Study (TIMSS) 2002, 2011 and 2015. It was thus no surprise that TIMSS 2015 found that the average mathematics score of South African learners was 376 out of a possible 1000 (Mullis, Martin, Foy \& Hooper, 2016). Out of the 48 countries who participated in TIMSS 2015, South Africa ranked second-last, only outperforming Kuwait (Mullis et al., 2016). Only 1\% of South African Grade 5 learners performed at the advanced international benchmark level (achieving above 625) and only 4\% at the high international benchmark level (achieving 550 to 625) (Reddy et al., 2017). These results indicated that only a handful of South African Grade 5 learners used their skills and knowledge in order to solve complex mathematical problems. The integration of ICTs in education may be a strategy that will improve the mathematics achievement and this is considered next.

Literature showed that numerous researchers analysed data from large international comparative studies, such as the TIMSS and the Programme for International Learner Assessment (PISA), in order to investigate the relationship between the use of ICTs and learner achievement in mathematics. Some results found positive relationships whereas others found negative relationships. The former is discussed first. Positive relationships 
between the use of ICTs and learner's mathematics achievement have been found by many; see, for example, Balanskat, Blamire and Kefala (2006), Bulut and Cutumisu (2017), Demir and Kiliç (2009), Falck, Mang and Woessmann (2018), Kubiatko and Vlckova (2010), Luu and Freeman (2011), Spiezia (2010) and Ponzo (2011). A panEuropean literature review by Balanskat, Blamire and Kefala (2006) indicated that, in Organisation for Economic Cooperation and Development (OECD) countries, there is a positive correlation between the time ICTs are used and learners' performance in the PISA mathematics tests. Internet usage in educational spaces in particular, resulted in noteworthy improvement in learners' performances. Interactive whiteboards are also one of the ICTs linked with increases in learners' performance, particularly for lowachieving pupils in English and mathematics. Bulut and Cutumisu (2017) used PISA 2012 data to determine whether the use of ICTs has an impact on learners' mathematics achievement. Their findings showed that learners who have computers available at home and school tend to perform better in mathematics. Similarly, the results of Skryabin, Zhang, Liu and Zhang (2015) and Petko, Cantieni and Prasse (2017) showed a significant positive relationship between learners who used computers at home and their mathematics achievement. Skryabin et al. (2015) found that the more frequently Grade 8 learners used computers at home, specifically for schoolwork, the better their mathematics achievement. The use of computers at home could also have provided learners with a more interactive approach in understanding mathematical concepts in a virtual setting which could have resulted in better mathematics scores (Kul, Celik \& Aksu, 2018).

Turning to negative relationships between the use of ICTs and learners' mathematics achievement, Ayieko, Gokbel and Nelson (2017) analysed data from TIMSS 2011 in order to investigate the relationship between computer use and learners' scores in mathematics in Taiwan, Singapore and Finland. The authors found that when learners in Taiwan used computers at their homes as well as in school, they tended to have lower mathematics reasoning scores. Eickelmann, Gerick and Koop (2017) used the PISA 2012 data of five countries in order to explore the relationship between the use of ICTs in mathematics instruction and Grade 9 learner achievement. One of their findings indicated a negative relationship concerning the use of computers for tasks such as "drawing the graph of a function, constructing geometric figures, entering data in a spreadsheet and finding out how the graph of a function like $y=\mathrm{ax}^{2}$ changes depending on a" (Eickelmann et al., 2017, p. 14). This implied that, the more learners used computers for those selected activities, the worse they performed (this was found for Germany and the Netherlands). In a South African context, Kruger (2018) investigated the relationship between the investment in ICTs in learning and teaching and mathematics achievement, based on TIMSS 2011 and TIMSS 2015. The results showed that South African learners performed worse if they used computers regularly to search for mathematical principles, including concepts, and if they practised mathematics skills and procedures on computers, than their counterparts who did not regularly make use of computers for these tasks. These learners also achieved lower mathematics scores if they often used computers to search for ideas and information and if they often processed and 
analysed data on the computer. Kruger (2018) also found that the more often learners used computers at home, the lower their mathematics results.

\section{Factors Affecting the Integration of ICT by Mathematics Teachers in the Classroom}

It is evident that more research needs to be done to determine what motivates teachers to integrate ICTs. The primary research question, therefore, of this study was "how does the UTAUT variables (Performance Expectancy, Effort Expectancy, Social Influence and Facilitating Conditions) influence mathematics teachers' acceptance of ICT integration?"

To best address the research question, the researcher made use of Venkatesh, Morris, Davis and Davis's (2003), Unified Theory of Acceptance and Use of Technology (UTAUT) framework. The UTAUT framework is a combination of the following models:

Theory of Reasoned Action (TRA), Technology Acceptance Model (TAM), Motivational Model (MM), Theory of Planned Behavior (TPB), Combined TAM and TPB (C- TAM-TPB), Model of PC Utilization (MPCU), Innovation Diffusion Theory (IDT) and (Social Cognitive Theory (Venkatesh et al., 2003, p. 425)

The UTAUT framework consists of four determining constructs and four moderators. In the framework (Figure 1), four main constructs namely Performance Expectancy (PE), Effort Expectancy (EE), Social Influence (SI) and Facilitating Conditions (FC) are perceived by Venkatesh et al. (2003) to directly influence whether or not a person would accept and use technology (use behaviour). Gender, age, experience and voluntariness are the moderators that impact the latter (see Figure 1).

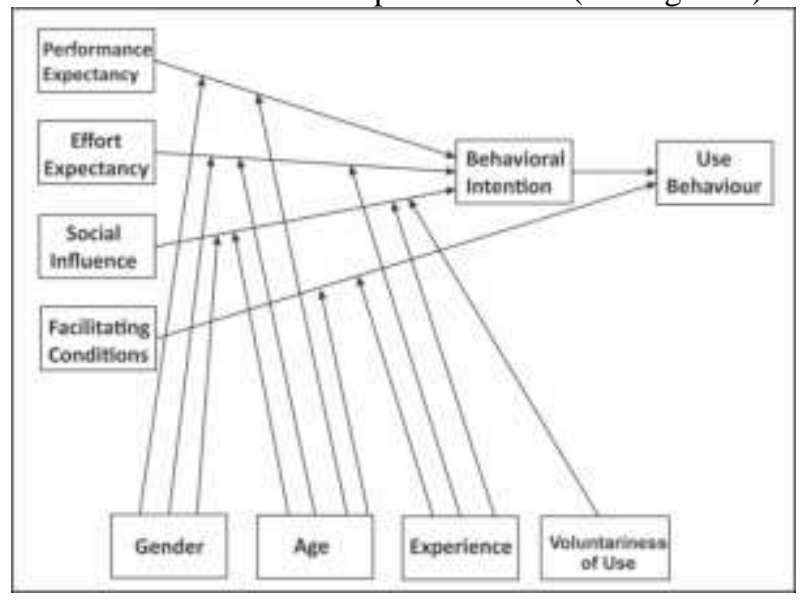

Figure 1

Unified Theory of Acceptance and Use of Technology (UTAUT) (Venkatesh et al., 2003, p. 447) 
Venkatesh et al. (2003) define Performance Expectancy (PE) as the amount to which a person believes that using ICT will assist the latter in enhancing their job performance. For this study, PE was defined as the degree to which mathematics teachers consider that utilising technology in the classroom will enhance the teaching and learning environment. Effort Expectancy (EE), according to (Venkatesh et al., 2003) relates to an individual's apparent ease of use of ICT. In this study, EE was viewed as a mathematics teacher's perceived effortless use of ICT for the teaching and learning of mathematics, which might influence his/her intention to use ICT. Social Influence (SI) is a person's opinion on what people who are significant to them, think about their use of ICT (Venkatesh et al., 2003). SI, in this study, was defined as a mathematics teacher's opinion on what other significant people (such as their principal, subject-head and colleagues), perceive hislher use of technology to be. Venkatesh et al. (2003) further define Facilitating Conditions (FC), as the level of a person's perception that administrative and technical infrastructure exists to encourage and support the usage of ICT. The degree to which a mathematics teacher perceives that skills, knowledge, resources and support regarding the use of ICT exist to support the use of ICT for the teaching and learning of mathematics was viewed as FC in this study. Finally, the first three constructs (PE, EE and SI) of the UTAUT framework are theorised to influence Behavioural Intention (BI) (Venkatesh et al., 2003). BI is referred to, in this study, as the mathematics teachers' intention to use ICT for teaching and learning of mathematics. The researchers attempted to measure a teachers' intention to use technology in the next six months since completing the questionnaire. According to Venkatesh et al. (2003), FC and BI are predicted to influence (actual) "use behaviour" of technology. The (actual) "use behaviour" is defined in this study as the mathematics teacher's actual use of technology for teaching and learning. As such, this study predicts that mathematics teachers' intention to use technology for teaching and learning will determine their actual use of technology for teaching and learning.

In this study, the UTAUT model was utilised to elicit a deeper understanding of the factors that will influence mathematics teachers' intention, to use technologies for the teaching and learning of mathematics. However, it should be pointed out that, since the study focused on specifically what technologies are being integrated by mathematics teachers, it was believed that all teachers use some form of technologies. Therefore, technologies use in schools was not viewed as voluntary but as an obligation and experience and voluntariness of use subsequently removed from the model. Moreover, the aim of this study was not to see, for example, whether females made more (or less) use of technologies in the classroom than males or whether younger respondents made more (or less) use of technologies in the classroom than older respondents and, therefore, gender and age were also excluded as moderators. Before the SEM model was run, an exploratory factor analysis (EFA) and a confirmatory factor analysis (CFA) was conducted. Details are omitted here to conserve space. From the EFA and CFA, it was found that the factor 'facilitating conditions' was dropped from the model. Only three factors remained after the EFA and CFA, namely, performance expectancy, effort expectancy and social influence. Structural equation modelling provides a basis for hypothesis testing and the hypotheses are as follows: 
Hypothesis 1:

$\mathrm{H}_{0}$ : Performance expectancy (PE) has no significant effect on behavioural intention (BI)

$\mathrm{H}_{\mathrm{a}}$ : Performance expectancy (PE) has a significant effect on behavioural intention (BI)

Hypothesis 2:

$\mathrm{H}_{0}$ : Effort expectancy (EE) has a no significant effect on behavioural intention (BI)

$\mathrm{H}_{\mathrm{a}}$ : Effort expectancy (EE) has a significant effect on behavioural intention (BI)

Hypothesis 3:

$\mathrm{H}_{0}$ : Social influence (SI) has no significant effect on behavioural intention (BI)

$\mathrm{H}_{\mathrm{a}}$ : Social influence (SI) has a significant effect on behavioural intention (BI)

Hypothesis 4:

$\mathrm{H}_{0}$ : Behavioural intention (BI) has no significant effect on actual use (USE)

$\mathrm{H}_{\mathrm{a}}$ : Behavioural intention (BI) has a significant effect on actual use (USE)

\section{METHOD}

The four hypotheses mentioned in the previous section were tested using a SEM model which is discussed later on. In this section the research design, participants, instrument, data collection and data analysis are discussed.

\section{Research Design}

As a critical realist, the researcher believes that a greater reality, free of our beliefs or ideas exists. Critical realism strives to learn about observable and non-observable constructs, free of events produced by them (Krauss, 2005). Utilising a post-positivistic critical realist paradigm, the researchers aimed to study the interactions between humans and machines and realising that the results were fallible and not necessarily generalisable.

\section{Participants}

In identifying and selecting respondents, purposeful and convenient sampling methods were employed, as the researchers had convenient access to a group of in-service mathematics teachers. Purposive sampling was also utilised, because the sample set shared a common attribute i.e. all of the participants were in-service mathematics teachers. Patton (2002) explains that in purposive sampling, the sample is purposefully selected from those individuals who have experience with the studied phenomenon. To obtain as large a response as possible, the use of both a hard copy questionnaire as well as an online survey was utilised. Hard copies were distributed at professional development sessions that teachers attended, whilst the link to the website was sent electronically to teachers. In total 191 teachers completed the questionnaires.

\section{Instrument}

The questionnaire comprised five sections: 
- Section A captured the demographic data of the participants.

- Section B recorded the different types of technologies accessible to participants.

- Section C was based on the Unified Theory of Acceptance and Use of Technology (UTAUT) framework and investigated the reasons why participants were utilising technologies in the teaching and learning environment.

- Section D was based on the SAMR model and attempted to understand, at a deeper level, how the participants integrated technology.

- Section E recorded participants' intention to use technology versus their actual use of it.

The focus of the current article was on Sections A, B, C and E of the questionnaire. Reliability and validity concerns were addressed using Cronbach's Alpha and construct validity, respectively.

\section{Data Collection}

The first source of data colletion was several provincial Department of Basic Education mathematics co-ordinators who willingly distributed the on-line questionnaire on behalf of the researchers to their respective clusters of mathematics teachers. The second source was a non-profit organisation called the School Support Centre. This organisation is a member society that prides itself on delivering a range of quality services to its members (mostly Afrikaans-speaking, in-service mathematics teachers). These services include the likes of mathematical worksheets, lesson plans, short professional development courses and two annual mathematics conferences. The School Support Centre voluntarily distributed the on-line questionnaire to its full member database of approximately 1000 in-service mathematics teachers.

\section{Data Analysis}

For data analyses, both descriptive and inferential statistics were used to provide different insights into the nature of the data gathered. Structural equation modelling (SEM) was used, using SPSS with its add-on AMOS, in order to analyse the structural relationship between measured variables and constructs.

\section{FINDINGS}

Of the respondents who completed the questionnaire, most were female (79\%). The majority of the respondents were between 50 and 59 years old (29.32\%) and had taught mathematics at secondary schools during the last five years. At primary school level, the majority taught Grade 5 and/or 7 mathematics, with $15.81 \%$ of the respondents overall having taught Grade 5 and/or Grade 7 mathematics. The secondary school respondents were relatively evenly spread among the different grades, with most of them having taught Grade $10(55.50 \%)$ during the previous five years. Table 1 indicates that respondents predominantly taught at city schools $(68.06 \%)$, while a considerably smaller number $(26.18 \%)$ worked in rural areas and only eleven $(5.76 \%)$ taught in township 
schools. By far, the majority of respondents were employed in public schools (89.53\%), and a mere $10.47 \%$ taught in private schools.

Table 1

Schools' Location where Respondents Teach

\begin{tabular}{lll}
\hline Location & Frequency & Percentage \% \\
\hline City & 130 & $68.06 \%$ \\
Rural & 50 & $26.18 \%$ \\
Township & 11 & $5.76 \%$ \\
\hline
\end{tabular}

It should be noted from Table 2 that while an attempt was made to distribute the esurvey link across the entire South Africa, this was not very successful. The participants came predominantly from city schools where technologies are readily available especially in the provinces of Gauteng (45.03\% of participants) and the Western Cape (21.47\% of participants). These two provinces focus intensively on technology integration and they have various implementation plans running. Furthermore, to add clarification on the background of the participants, the on-line questionnaire was made available in both English and Afrikaans. The majority of participants (84.81\%) completed the Afrikaans questionnaire and only $15.19 \%$ completed the English version.

Table 2

Provinces where Participating Teachers Teach

\begin{tabular}{lll}
\hline Province & Frequency & Percentage \% \\
\hline Gauteng & 86 & $45.03 \%$ \\
Western Cape & 41 & $21.47 \%$ \\
Eastern Cape & 13 & $6.81 \%$ \\
North West & 15 & $7.85 \%$ \\
Free State & 7 & $3.66 \%$ \\
Limpopo & 16 & $8.38 \%$ \\
KwaZulu-Natal & 7 & $3.66 \%$ \\
Mpumalanga & 5 & $2.62 \%$ \\
Northern Cape & 1 & $0.52 \%$ \\
\hline
\end{tabular}

The focus of this article was an attempt to identify the factors as to why teachers integrate ICT into the teaching and learning of mathematics. From the framework (Figure 1) it was hypothesised that FC and BI (headed by PE, EE, SI) would predict the influence on actual "use behaviour" of ICT, within the educational domain. The participating teachers were given 29 statements developed from the UTAUT framework and asked to select a number that best described their agreement or disagreement with each statement on a five-point Likert scale, with $1=$ "Disagree"; 2 = "Somewhat Disagree"; 3 = "Neutral"; 4 = "Somewhat Agree" and 5 = "Agree". An exploratory factor analysis (EFA) was done to check whether or not there were indeed four factors (FC, PE, EE and SI). The EFA indicated that there were indeed four factors since four of the eigenvalues are greater than one (Field, 2014, p. 697). Factor 1 explains 58.3\% of the total variance which is much more than the other factors which explain 6\% (Factor 2), $4.4 \%$ (Factor 3), 3.8\% (Factor 4) of the total variance, respectively. It was also observed that questions 9.4, 9.8, 9.12 and 9.16 which the researcher thought would load onto the same factor FC, did not. To investigate this further a confirmatory factor 
analysis (CFA) was done. Using the items proposed from the literature review a proposed measurement model was created for the CFA. However, there was an unacceptable level of model fit as indicated by all the model-fit indices being below their respective common acceptable levels (Hu \& Bentler, 1999, Kline, 2012). See Table 3 for a summary of the statistics of the purposed theoretical model.

Table 3

Summary of the Statistics of the Complete Theoretical Model

\begin{tabular}{lll}
\hline Statistic & Acceptable level & $\begin{array}{l}\text { Value for the complete } \\
\text { theoretical model }\end{array}$ \\
\hline $\begin{array}{l}\text { Normed Chi-square (CMIN/DF) } \\
\text { p-value of the Chi-square test statistic }\end{array}$ & $\begin{array}{l}\text { Between 1 and 2 } \\
\text { p-value }>0.05\end{array}$ & $\begin{array}{l}4.343 \text { - unacceptable } \\
0.001-\text { unacceptable }\end{array}$ \\
$\begin{array}{l}\text { Root mean-square error of approximations } \\
\text { Goodness-of-fit index (GFI) }\end{array}$ & RMSEA $<0.08$ & 0.133 - unacceptable \\
Comparative fit index (CFI) & GFI $>0.80$ & 0.648 - unacceptable \\
\hline
\end{tabular}

Based on the recommendations put forward by Hair, Black, Babin and Anderson (2010), there are a number of steps that can be taken to improve goodness of fit (GOF). Firstly, factors with low loadings can be dropped (Hair et al., 2010). In order to find the items that were loading poorly, the standardised regression weights in the AMOS output were investigated and all items with loadings less than 0.7 were deleted. Ideally, each factor should have a minimum of three items, although if some constructs had less than three, it would still be acceptable (Iacobucci, 2010). This process was repeated several times until the acceptable model fit (Figure 2) was reached.

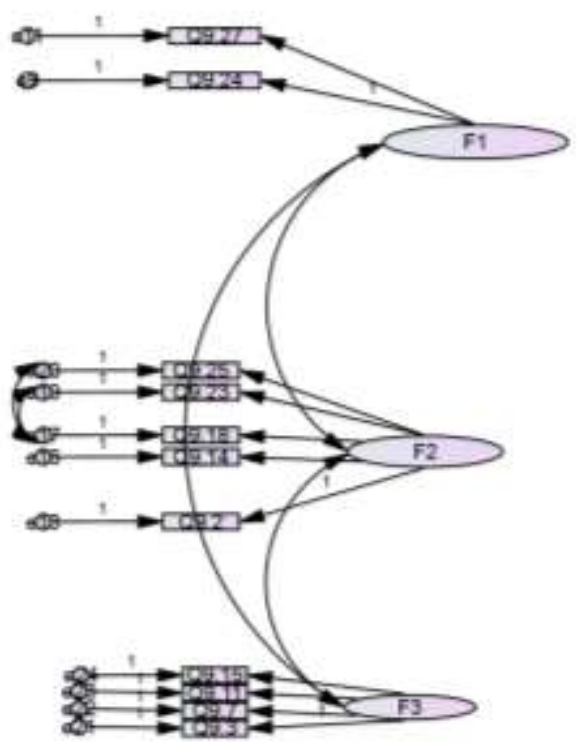

Figure 2

CFA for the Acceptable Theoretical Model 
Table 4

Summary of the Statistics of the Acceptable Model

\begin{tabular}{lll}
\hline Statistic & Acceptable level & $\begin{array}{l}\text { Value for the complete theoretical } \\
\text { model }\end{array}$ \\
\hline Normed Chi-square (CMIN/DF) & Between 1 and 2 & 1.865 \\
p-value of the Chi-square test statistic & p-value $>0.05$ & 0.103 \\
Root mean-square error of & RMSEA $<0.08$ & 0.067 \\
approximations (RMSEA) & GFI $>0.90$ & 0.936 \\
Goodness-of-fit index (GFI) & CFI $>0.90$ & 0.982 \\
Comparative fit index (CFI) &
\end{tabular}

As can be seen from the model fit summary in Table 4, the GOF indices indicated that this model was considerably better. It should be noted that from the model above there is only three factors (and not four with only having two items loading meaningfully onto Factor 1, five items onto Factor 2 and four items onto Factor 3). The factor FC was therefore dropped from the model. The UTAUT model in Figure 1 was amended and the testing of this amended model was done using SEM, noting that the moderation effects were not taken into consideration. Informed by the literature, the EFA and the CFA, the four hypotheses stated earlier were created.

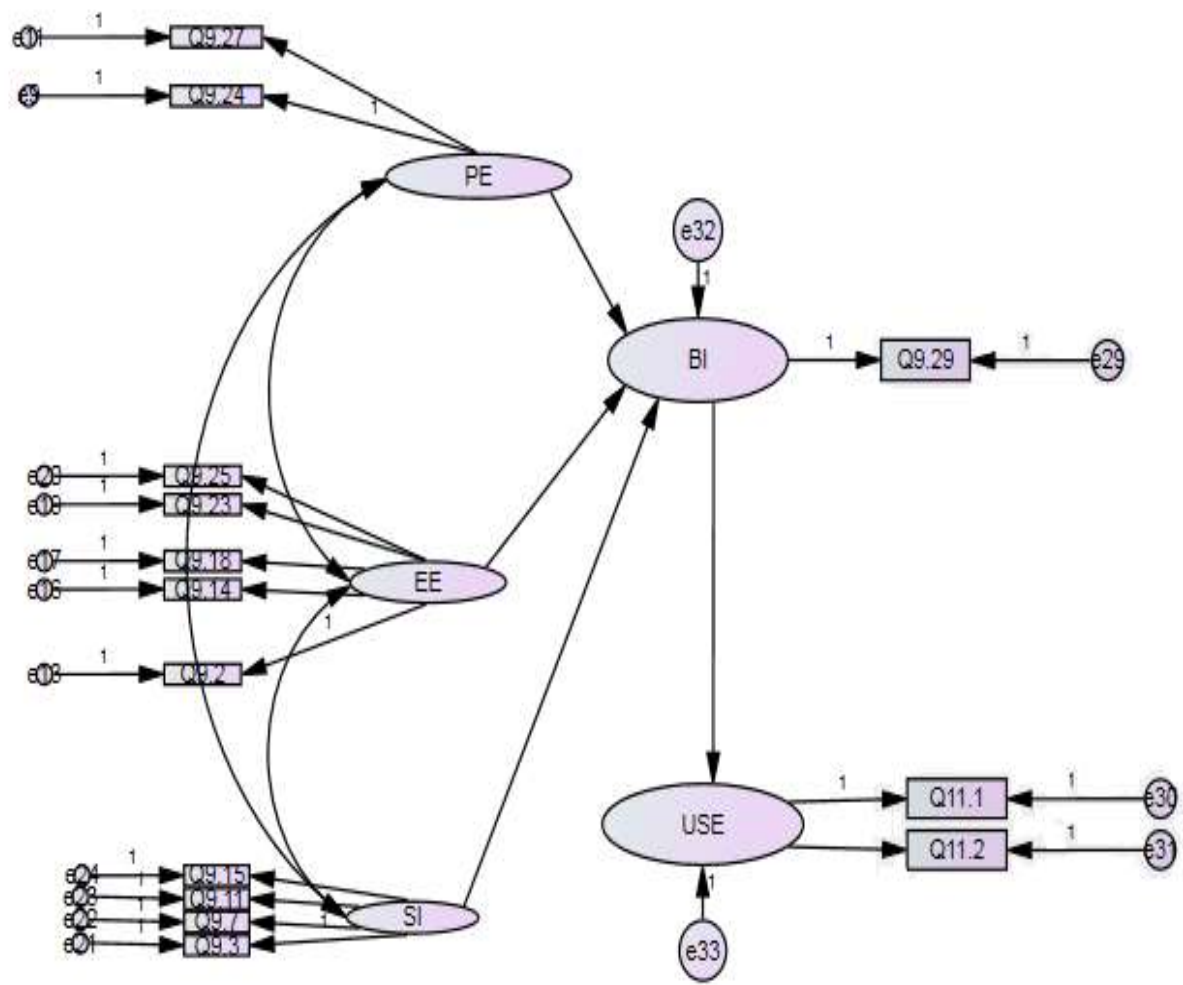

Figure 3

Structural Equation Model

International Journal of Instruction, April $2020 \bullet$ Vol.13, No.2 
Table 5

Summary of the Statistics of the SEM

\begin{tabular}{lll}
\hline Statistic & Acceptable level & Value for the complete theoretical model \\
\hline $\begin{array}{l}\text { Normed Chi-square (CMIN/DF) } \\
\text { p-value of the Chi-square test statistic }\end{array}$ & Between 1 and 2 & 1.547 - acceptable \\
Root mean-square error of & RMSEA $<0.05$ & 0.241 - acceptable \\
approximations (RMSEA) & GFI $>0.80$ & 0.054 - acceptable \\
Goodness-of-fit index (GFI) & CFI $>0.90$ & 0.925 - acceptable \\
Comparative fit index (CFI) & 0.984 - acceptable \\
\hline
\end{tabular}

Table 6

Structural Equation Modeling Results

\begin{tabular}{llll}
\hline Path (hypothesis) & t-test & p-value & Hypothesis testing result \\
\hline PE $\rightarrow$ BI (Hypothesis 1) & 2.302 & 0.021 & $\mathrm{H}_{0}$ rejected, PE has an effect on BI. \\
EE $\rightarrow$ BI (Hypothesis 2) & 1.466 & 0.143 & $\mathrm{H}_{0}$ not rejected, EE has no effect on BI. \\
SI $\rightarrow$ BI (Hypothesis 3) & 4.351 & $<0.001$ & $\mathrm{H}_{0}$ rejected, SI has an effect on BI. \\
BI $\rightarrow$ USE (Hypothesis 4) & 7.162 & $<0.001$ & $\mathrm{H}_{0}$ rejected, BI has an effect on actual USE. \\
\hline
\end{tabular}

From Table 6 it can be seen that three of the four paths were statistically significant. The the first hypothesis the findings reveal that the PE construct positively predicted the BI construct $(\mathrm{t}=2.302$, $\mathrm{p}$-value $=0.021)$. This finding concurs with multiple studies in the literature that also examined the effect of PE on BI (Moran, Hawkes \& Gayar, 2010; Wong, Russo \& McDowall, 2013; Wong, Teo \& Goh, 2015). For the second hypothesis the findings reveal that EE did not significantly predict the BI construct $(\mathrm{t}=1.466$, $\mathrm{p}$ value $=0.143)$. Within the body of literature available on the UTAUT, there are different findings with regards to the influences of EE. Some studies show that EE has no influence on BI (Jong \& Wang, 2009; Park, 2009; Šumak, Polancic \& Hericko, 2010; Venkatesh et al., 2003) while others indicate that a significant influence does exist as is the case in this study (Boontarig, Chutimaskul, Chongsuphajaisiddh, \& Papasratorn, 2012; El-Gayar \& Moran, 2006; Martins \& Kellermanns, 2004; Oye, Iahad \& Rahim, 2012; Yamin \& Lee, 2010). For the third hypothesis, it was found that the SI construct positively predicted the BI construct $(\mathrm{t}=4.351$, $\mathrm{p}$-value $<0.001)$. The latter is in agreement with the various literature (Moran et al., 2010; Teo, 2011; Wang \& Shih, 2009). For the fourth hypothesis, the SEM indicated that the BI construct positively predicted the USE construct $(\mathrm{t}=7.162$, $\mathrm{p}$-value $<0.001)$. This finding concurs with the results from similar studies in the literature (Meng \& Wang, 2018; Moran et al., 2010).

\section{DISCUSSION}

The positive effect of PE on BI found is indicative that respondents believe using ICT improves their teaching performance. The latter combined with the fact that EE did not significantly predict intentional use of ICT, could be interpreted as teachers not necessarily using ICT because it is easier to learn and use, but rather because it improves their teaching performance. Moreover, this might also be linked to the fact that FC was not seen as a predicting factor of intentional use of ICT. With ICT becoming more obligatory and available in educational institutions, it could be that teachers have learned a coping mechanism to resolve difficulties linked to the use of hardware and software and do not see this as a predicting factor. This could therefore also be related 
to the finding of Ertmer and Ottenbreit-Leftwich (2012, 2013), who found that access to ICT is no longer a significant barrier to its integration. Furthermore, the strong positive effect of SI is indicative that the use of ICT was perceived as a necessity by the individuals who were important for the respondents, as also suggested in other studies (Moran et al., 2010; Teo, 2011). If the number of teachers who adopt and use ICT is increased to a significant level, the participation of the other non-adopting teachers might increase quicker. Lastly, because teachers' intention to use ICT does, in fact, predict the actual use of ICT (positive effect of BI on actual "use behaviour") for teaching and learning of mathematics, it could also be that the use of ICT in the future would be adopted if PE and SI were present.

\section{CONCLUSION AND RECOMMENDATION}

Vitanova, Atanasova-Pachemska, Iliev and Pachemska (2015) asserts that despite the perceptible presence and the rapid evolution of technology in education, the difficulties and the demands, that the usage of technology in teaching comprises, constitute a subject of intense debate. Mueller and Wood (2012) suggests that ICT integration at the actual classroom level remains a perplexing challenge, as literature reveals that the introduction of technology into the education system over the last two decades has not brought about the progress and impact as was expected, despite its potential (BuabengAndoh, 2012; Whitworth, 2012). The data from this study indicated that even if adequate resources and technical support are available and teachers have sufficient knowledge of technology, it does not mean that they will use it. The data further highlights the fact that it is not necessarily worthwhile for governments and schools to spend ample amounts of money on the latest technology if teachers lack the pedagogical knowledge to integrate it successfully. The latter is confirmed by recent research that suggests many teachers, globally, lack the technological competences to develop innovative levels of teaching (Koehler et al., 2014; Moersch, 2016).

Concerning the hypotheses raised, for the first hypothesis the findings reveal that the performance expectancy construct positively predicted the behavioural intention (BI) construct. This indicates that teachers believe that the use of ICT improves the teaching performance. For the second hypothesis the findings revealed that effort expectancy did not significantly predict the BI construct. With effort expectancy not significantly predicting intentional use of ICT, it could be translated as teachers not necessarily using ICT because it is easier or more difficult to learn and use. For the third hypothesis it was found that the social influence (SI) construct positively predicted the behavioural intention (BI) construct. The strong positive effect of social influence is the result that the use of ICT was deemed necessary by the people who were important for the participating teachers, as also suggested in other literature (Moran et al., 2010; Teo, 2011). Finally, for the fourth hypothesis the findings revealed that the behavioural intention (BI) construct positively predicted the actual use behaviour (USE) construct. Thus, teachers' intention to use ICT does in fact predict the actual use of ICT for teaching and learning of mathematics, thereby confirming the finding of Venkatesh et al. (2003). 
In summary, the findings are indicative that teachers might only view technology integration as beneficial when it increases productivity and social influence. However, as McCormick and Scrimshaw (2001) point out, the potential of ICT may not be realised unless it is seen as more than just an aid to efficiency, or an extension device. The researchers of this study, therefore, propose that ways be found to motivate mathematics teachers to use technology not only to increase teacher productivity but also to foster pedagogical changes and improve conceptual understanding in the teaching and learning of mathematics. The National Council of Teachers of Mathematics (NCTM) recommends that learners use ICT for solving real-life problems, rather than tedious calculations (Ittigson \& Zewe, 2003). This fundamental shift needed in teacher pedagogy can perhaps be attained through professional development programmes that model functional pedagogical changes to teachers and could lead to improved mathematics education in South Africa.

\section{ACKNOWLEDGEMENTS}

The authors acknowledge the financial support of the South African National Research Foundation (NRF), project no. 90389.

\section{REFERENCES}

Ayieko, R. A., Gokbel, E. N., \& Nelson, B. (2017). Does computer use matter? The influence of computers on students' mathematics reasoning. Forum for International Research in Education, 4(1), 67-87. https://doi.org/10.18275/fire201704011120.

Balanskat, A., Blamire, R., \& Kefala, S. (2006). The ICT impact report. European Schoolnet, 1, 1-71.

Boontarig, W., Chutimaskul, W., Chongsuphajaisiddh, V., \& Papasratorn, B. (2012). Factors influencing the Thai elderly intention to use smartphone for e-Health services. In 2012 IEEE Symposium on Humanities, Science and Engineering Research (pp. 479483). IEEE.

Brenner, A. M., \& Brill, J. M. (2016). Investigating practices in teacher education that promote and inhibit technology integration transfer in early career teachers. TechTrends, 60(2), 136-144.

Buabeng-Andoh, C. (2012). Factors influencing teachers' adoption and integration of information and communication technology into teaching: A review of the literature. International Journal of Education and Development using Information and Communication Technology, 8(1), 136-155.

Bulut, O., \& Cutumisu, M. (2017). When technology does not add up: ICT use negatively predicts mathematics and science achievement for Finnish and Turkish students in PISA 2012. In EdMedia: World Conference on Educational Media and Technology (pp. 935-945). Association for the Advancement of Computing in Education (AACE). 
Carver, L. B. (2016). Teacher perception of barriers and benefits in K-12 technology usage. Turkish Online Journal of Educational Technology, 15(1), 110-116.

Demir, I., \& Kiliç, S. (2009). Effects of computer use on students' mathematics achievement in Turkey. Procedia - Social and Behavioral Sciences, 1(1), 1802-1804.

Department of Basic Education. (2015). Action Plan to 2019: Towards the Realisation of Schooling 2030. Pretoria: Department of Basic Education. Retrieved from https://www.education.gov.za/Portals///Documents/Publications/Action\%20Plan\%2020 19.pdf?ver=2015-11-11-162424-417.

Eickelmann, B., Gerick, J., \& Koop, C. (2017). ICT use in mathematics lessons and the mathematics achievement of secondary school students by international comparison: Which role do school level factors play? Education and Information Technologies, 22(4), 1527-1551. https://doi.org/10.1007/s10639-016-9498-5.

El-Gayar, O. F., \& Moran, M. (2006). College students' acceptance of Tablet PCs: An application of the UTAUT Model. Dakota State University, 820, 2845-2850. Retrieved from

http://citeseerx.ist.psu.edu/viewdoc/download?doi=10.1.1.120.2667\&rep=rep1\&type=p df.

Ertmer, P. A., Ottenbreit-Leftwich, A. T., Sadik, O., Sendurur, E., \& Sendurur, P. (2012). Teacher beliefs and technology integration practices: A critical relationship. Computers \& Education, 59(2), 423-435.

Ertmer, P. A., \& Ottenbreit-Leftwich, A. (2013). Removing obstacles to the pedagogical changes required by Jonassen's vision of authentic technology-enabled learning. Computers \& Education, 64, 175-182.

Falck, O., Mang, C., \& Woessmann, L. (2018). Virtually no effect? Different uses of classroom computers and their effect on student achievement. Oxford Bulletin of Economics and Statistics, 80(1), 1-38. https://doi.org/10.1111/obes.12192.

Field, A. (2014). Discovering statistics using IBM SPSS statistics. SAGE Publishers.

Gauteng Department of Education (GDE). (2015). Accessing quality special education for all in Gauteng 2015/16 MTEF Budget Speech - Vote 5: Education by Mr Panyaza Lesufi, Member of the Executive Council for Education Gauteng legislature. Johannesburg. $\quad$ Retrieved from http://www.education.gpg.gov.za/Media/Speeches/Documents/2016-

17\%20Budget $\% 20$ Speech\%20Ver\%209\%20print.pdf.

Hair, J. F., Black, W. C., Babin, B. J., \& Anderson, R. E. (2010). Multivariate data analysis: A global perspective. London, Essex: Pearson Education.

Hsu, P. S. (2016). Examining current beliefs, practices and barriers about technology integration: A case study. TechTrends, 60(1), 30-40. 
Hu, L. T., \& Bentler, P. M. (1999). Cutoff criteria for fit indexes in covariance structure analysis: conventional criteria versus new alternatives. Structural Equation Modeling: A multidisciplinary journal, 6(1), 1-55.

Iacobucci, D. (2010). Structural equations modeling: Fit indices, sample size, and advanced topics. Journal of Consumer Psychology, 20(1), 90-98.

Ittigson, R. J., \& Zewe, J. G. (2003). Technology in the mathematics classroom. In Challenges of teaching with technology across the curriculum: Issues and solutions (pp. 114-133). IGI Global.

Jong, D., \& Wang, T. S. (2009, May). Student acceptance of web-based learning system. Proceedings of the 2009 International Symposium on Web Information Systems and Applications (WISA'09) (pp. 533-536). People's Republic of China: Nanchang.

Karsenti, T., Collin, S., \& Harper-Merrett, T. (2011). Pedagogical integration of ICT: Successes and challenges from 100+ African Schools. Retrieved from https://depot.erudit.org/id/003775dd.

Kline, R. B. (2012). Assumptions in structural equation modeling. In R. H. Hoyle (Ed.), Handbook of structural equation modeling (pp. 111-125). New York, NY: Guilford Press.

Koehler, M. J., Mishra, P., Kereluik, K., Shin, T. S., \& Graham, C. R. (2014). The technological pedagogical content knowledge framework. In Handbook of research on educational communications and technology (pp. 101-111). New York, NY: Springer.

Krauss, S. E. (2005). Research paradigms and meaning making: A primer. The Qualitative Report, 10(4), 758-770.

Kruger, G. M. (2018). The relationship between investment in ICT and mathematics achievement (Unpublished doctoral dissertation). University of Pretoria, Pretoria, South Africa. $\quad$ Retrieved from https://repository.up.ac.za/bitstream/handle/2263/67752/Kruger_Relationship_2018.pdf ?sequence $=1 \&$ is Allowed $=\mathrm{y}$.

Kubiatko, M., \& Vlckova, K. (2010). The relationship between ICT use and science knowledge for Czech students: A secondary analysis of PISA 2006. International Journal of Science and Mathematics Education, 8(3), 523-543.

Kul, Ü., Çelik, S., \& Aksu, Z. (2018). The impact of educational material use on mathematics achievement: A meta-analysis. International Journal of Instruction, 11(4), 303-324.

Luu, K. \& Freeman, J. G. (2011). An analysis of the relationship between information and communication technology (ICT) and scientific literacy in Canada and Australia. Computers and Education, 56(4), 1072-1082. doi:10.1016/j.compedu.2010.11.008. 
Martins, L. L., \& Kellermanns, F. W. (2004). A model of business school students' acceptance of a web-based course management system. Academy of Management Learning \& Education, 3(1), 7-26.

McCormick, R., \& Scrimshaw, P. (2001). Information and communications technology, knowledge and pedagogy. Education, Communication \& Information, 1(1), 37-57.

Meng, H. J., \& Wang, T. Y. (2018). Acceptance of IWBs instruction and concomitant behavior through self-regulation learning. GSTF Journal on Computing, 1(4).

Moersch, C. (2016). Finding the missing link. Retrieved from http://loticonnection.cachefly.net/nbea/NBEA-FindingTheMissingLink- WhitePaper.pdf

Mooketsi, B. E. \& Chigona, W. (2014). Different shades of success: Educator perception of government strategy on e-education in South Africa. The Electronic Journal of Information Systems in Developing Countries, 64(8), 1-15.

Moran, M., Hawkes, M., \& Gayar, O. E. (2010). Tablet personal computer integration in higher education: Applying the unified theory of acceptance and use technology model to understand supporting factors. Journal of Educational Computing Research, 42(1), 79-101.

Mueller, J., \& Wood, E. (2012). Patterns of beliefs, attitudes, and characteristics of teachers that influence computer integration. Education Research International, 1-13. doi:10.1155/2012/697357.

Mullis, I. V. S., Martin, M. O., Foy, P., \& Hooper, M. (2016). TIMSS 2015 international results in mathematics. Chestnut Hill: TIMSS \& PIRLS International Study Center, Lynch School of Education, Boston College and International Association for the Evaluation of Educational Achievement (IEA). Retrieved from http://timssandpirls.bc.edu/timss2015/international-results/.

Mundy, M. A., Kupczynski, L., \& Kee, R. (2012). Teacher's perceptions of technology use in the schools. Sage Open, 2(1). doi: 10.1177/2158244012440813.

Nkula, K. \& Krauss, K. E. (2014). The integration of ICTs in marginalized schools in South Africa: Considerations for understanding the perceptions of in-service teachers and the role of training. Proceedings of the ${ }^{\text {th }}$ International Development Informatics Association (IDIA) conference (pp. 241-261).

Oye, N. D., Iahad, N., \& Rahim, N. Z. (2012). The impact of UTAUT model and ICT theoretical framework on university academic staff: Focus on Adamawa State University, Nigeria. International Journal of Computers \& Technology, 2(2), 102-111.

Padayachee, K. (2016). A stepwise framework toward ICT integration in Education: A South African perspective. Paper presented the $3^{\text {rd }}$ IEEE International Conference on Advances in Computing, Communication and Engineering, Durban, South Africa. 
Park, S. Y. (2009). An analysis of the technology acceptance model in understanding university students behavioral intention to use e-learning. Educational Technology \& Society, 12(3), 150-162.

Patton, M. Q. (2002). Qualitative research and evaluation methods. Thousand Oaks, CA: Sage Publications.

Petko, D., Cantieni, A., \& Prasse, D. (2017). Perceived quality of educational technology matters: A secondary analysis of students' ICT use, ICT-related attitudes and PISA 2012 test scores. Journal of Educational Computing Research, 54(8), 1070-1091. doi:10.1177/0735633116649373.

Ponzo, M. (2011). Does the way in which students use computers affect their school performance? Journal of Economic and Social Research, 13(2), 1-27.

Reddy, V., Isdale, K., Juan, A., Visser, M., Winnaar, L., \& Arends, F. (2017). Highlights of mathematics achievement amongst Grade 5 South African learners. Human Sciences Research Council. Retrieved from https://www.che.ac.za/sites/default/files/TIMSS\%202015\%20Grade\%205\%20Highlight s\%20document.pdf .

Reddy, V., Prinsloo, C., Arends, F., Visser, M., Winnaar, L., Feza, N., Rogers, S., Janse van Rensburg, D., Juan, A., Mthethwa, M., Ngema, M., \& Maja, M. (2012). Highlights from TIMMS 2011: The South African perspective. South Africa, Pretoria: Human Science Research Council. Retrieved from http://www.hsrc.ac.za/en/researchoutputs/view/6480.

Reddy, V., Visser, M., Winnaar, L., Arends, F., Juan, A., Prinsloo, C. H., \& Isdale, K. (2016). TIMSS 2015: Highlights of mathematics and science achievement of grade 9 South African learners. South Africa, Pretoria: Human Sciences Research Council. Retrieved from http://repository.hsrc.ac.za/bitstream/handle/20.500.11910/10673/9591.pdf?sequence=1 \&isAllowed $=\mathrm{y}$.

Skryabin, M., Zhang, J., Liu, L., \& Zhang, D. (2015). How the ICT development level and usage influence student achievement in reading, mathematics, and science? Computers \& Education, 85, 49-58. https://doi.org/10.1016/j.compedu.2015.02.004.

Spiezia, V. (2010). Does computer use increase educational achievements? Studentlevel evidence from PISA. OECD Journal: Economic Studies, 2010(1), 127-148.

Šumak, B., Polancic, G., \& Hericko, M. (2010). An empirical study of virtual learning environment adoption using UTAUT. 2010 Second International Conference on Mobile, Hybrid, and On-Line Learning (pp. 17-22). IEEE

Teo, T. (2011). Modeling the determinants of pre-service teachers' perceived usefulness of e-learning. Campus-Wide Information Systems, 28(2), 124-140.

Venkatesh, V., Morris, M. G., Davis, G. B., \& Davis, F. D. (2003). User acceptance of information technology: Toward a unified view. MIS Quarterly, 27(3), 425-478. 
Vitanova, V., Atanasova-Pachemska, T., Iliev, D., \& Pachemska, S. (2015). Factors affecting the development of ICT competencies of teachers in primary schools. Procedia-Social and Behavioral Sciences, 191, 1087-1094.

Wang, Y. S., \& Shih, Y. W. (2009). Why do people use information kiosks? A validation of the unified theory of acceptance and use of technology. Government Information Quarterly, 26(1), 158-165.

Whitworth, A. (2012). Invisible success: Problems with the grand technological innovation in higher education. Computers \& Education, 59(1), 145-155.

Wong, K. T., Teo, T., \& Goh, P. S. C. (2015). Understanding the intention to use interactive whiteboards: model development and testing. Interactive Learning Environments, 23(6), 731-747.

Wong, K. T., Russo, S., \& McDowall, J. (2013). Understanding early childhood student teachers' acceptance and use of interactive whiteboard. Campus-Wide Information Systems, 30(1), 4-16.

Yamin, M., \& Lee, Y. (2010). Level of acceptance and factors influencing student's intention to use UCSI University's e-mail system. 2010 International Conference on User Science and Engineering (pp. 26-31). IEEE. 